\title{
Essay
}

\section{LAW AND POLICY IN THE AGE OF THE INTERNET}

\author{
ROBERT E. LITAN†
}

\section{INTRODUCTION}

The world is just at the dawn of the Internet revolution, a revolution that promises both benefits and new sets of challenges, if not problems. The benefits manifest themselves in political, economic, and social dimensions. The policy challenges are more numerous, but four in particular have attracted significant attention: privacy, intellectual property protection, taxation, and "open access" to high-speed or "broadband" networks.

In this Essay, I survey the benefits of the Internet and then outline a framework for dealing with the aforementioned policy issues. ${ }^{1}$ My approach is eclectic. I doubt that the four issues will (or should) be resolved either by the market or by government alone, and thus I recommend a judicious mix of the two. I also want to be clear that in the fast-moving Internet environment, policymakers' first instinct should be to rely on markets and technology to address troublesome issues and to act only if there are identifiable market failures that can be corrected usefully by some type of government intervention. Fur-

Copyright $\odot 2001$ by Robert E. Litan.

$\dagger$ Vice President and Director, Economic Studies Program, and Cabot Family Chair in Economics at the Brookings Institution, Washington, D.C., and Co-Director of the AEIBrookings Joint Center on Regulatory Studies. The oral version of this Essay was presented as the 2000 Brainerd Currie Lecture at the Duke University School of Law on March 7, 2000. This written version also discusses a number of developments since March 2000, and thus it differs to some degree from the original presentation. I want to thank my colleague Robert Hahn, the editors at the Duke Law Journal for many helpful comments and suggestions, and Samara Potter for excellent research assistance.

1. For three of the most thorough discussions of the many of the issues analyzed here, see Lawrence Lessig, Code AND Other Laws of CyberspaCe (1999); CATHERINE L. MANN et Al., Global Electronic Commerce: A Policy Primer 13 (2000); and DevelopmentsThe Law of Cyberspace, 112 HARV. L. REV. 1574 (1999). 
thermore, when government action is warranted, it should maximize the opportunities for achieving social benefits while minimizing any disadvantages or downsides-a guide that is as applicable to the "real" world as it is to the "virtual" world.

Policy issues relating to the Internet have loomed larger as the use of the Net has grown. In just four years, the Net had attracted fifty million users, the fastest pace of adoption of any communications technology in history. By contrast, it took thirteen years for television and seventy-four years for the telephone to reach the same number of users. $^{2}$ As of January 2000, more than seventy-two million computers from more than 220 countries were connected to the Internet. ${ }^{3}$ Internet penetration is projected to continue increasing. Perhaps even more important, the speed of access is also projected to advance for any single user by leaps and bounds once various "broadband" technologies-cable, wireless, or enhanced services over conventional copper telephone lines-are installed more universally.

I shall assume that by now readers are familiar with the origins of the Internet and its basic features. ${ }^{4}$ The Internet was launched by the federal government as a tool for university researchers to communicate with each other and with the government. ${ }^{5}$ The Net has since become a vehicle or highway-or whatever metaphor one wants to choose-for commercial activity. This happened because of the development of browsers in the 1990s. ${ }^{6}$ Browsers enable users to find

2. Challenges to the Network: Internet for Development 4, International Telecommunications Union, at http://www.itu.int/ti/publications/INET_99/chal_exsum.pdf (Oct. 1999) (on file with the Duke Law Journal).

3. MANN ET AL., supra note 1, at 13.

4. For more thorough accounts of the Internet's history and origins, see TIM BERNERSLeE \& Mark Fischetti, Weaving the Web: The Original Design and Ultimate DESTINY OF THE World WIDE Web BY ITS InVENTOR (1999); A. Michael Froomkin, Wrong Turn in Cyberspace: Using ICANN to Route Around the APA and the Constitution, 50 DUKE L.J. 17 (2000); and Jonathan Weinberg, ICANN and the Problem of Legitimacy, 50 DUKE L.J. 187 (2000). For a more detailed legal guide to the many of the issues treated here, see Developments-The Law of Cyberspace, supra note 1.

5. The Internet was initially developed by the Defense Department in the late 1960s. LESSIG, supra note 1, at 4.

6. The initial browser, Gopher, was developed by researchers at the University of Minnesota and was text-based. Shortly thereafter, Marc Andreesan and his colleagues at the University of Illinois developed the more user-friendly Mosaic, which was later commercialized by Netscape. Microsoft followed with a similar browser, Internet Explorer, which the company incorporated in its Windows operating system-a step that led to the now well-known antitrust case that the government successfully brought against the company. United States v. Microsoft Corp., 97 F. Supp. 2d 59 (D.D.C. 2000) (order); United States v. Microsoft Corp., 87 F. Supp. 2d 30 (D.D.C. 2000) (conclusions of law); United States v. Microsoft Corp., 84 F. Supp. 2d 9 (D.D.C. 2000) (findings of fact). At the time of this writing, that case is on appeal to the United 
what they are looking for on the Net virtually instantaneously and thus enable commerce. The development of commerce, in turn, has generated strong and continuing demand for the Net itself. It is the use of the Net by private individuals and firms that has spawned debate about how, or whether, to translate various legal and policy frameworks familiar in the physical world to the world of "cyberspace," a world that seems to have no geographic location other than on the computers that reside on the network we call the Internet.

\section{THE BENEFITS OF THE INTERNET}

Internet enthusiasts have gushed about the potential promises of the Internet. Some proclaim it to be as important, if not more important, than the Industrial Revolution. That may turn out to be true, but frankly, no one will know for some time. In this part, I take a more pedestrian but still somewhat optimistic slant by briefly reviewing three ways the Internet is likely to prove beneficial (although not without some drawbacks).

\section{A. Political Benefits}

One of the most commonly noted political trends in America is the steady decline in voter turnout. Robert Putnam has described a parallel decline in civic involvement in his widely acclaimed Bowling Alone. In principle, the Internet can help offset this tendency by facilitating more direct contact between citizens and their government in many routine functions and by reducing the costs of connecting individuals with common viewpoints who otherwise may not know about each other in order to achieve shared ends.

At the government-to-citizen level, all levels of government in this country are already using the Net to make information available about their activities, how government money is spent, and how to register complaints and views with relevant agencies and officials. In addition, governments are trying to catch up to the commercial sector by offering ways to "do business" with the government-register cars, renew drivers' licenses, pay property and income taxes, and so onwithout having to show up physically at government offices and wait

States Court of Appeals for the District of Columbia Circuit after a decision by the Supreme Court in late September 2000 not to expedite review of the matter. Microsoft Corp. v. United States, 121 S. Ct. 25, 25 (2000).

7. Robert D. Putnam, Bowling Alone: The Collapse and Revival of AMERICAN COMMUNITY 48-64 (2000). 
in long lines. In all of these ways, the Net is bringing ordinary citizens in closer contact with their governments. This should, in turn, increase citizen involvement in governmental and political activities. ${ }^{8}$

In fact, there is evidence that this is happening. For example, in 1998 the FDIC proposed a set of rules designed to detect drug-related money laundering. 'These "Know Your Customer" rules would have required banks to obtain various types of information from potential clients before accepting their accounts. The rules generated a firestorm of protests from individuals and groups concerned about privacy, who promptly conveyed their views to the regulators. ${ }^{10}$ The response was so quick and overwhelming that the agency withdrew the proposed rules. ${ }^{11}$

More broadly, during the 2000 presidential primaries, each of the major candidates used websites to promote his views and, perhaps more significantly, to solicit money. Interestingly, the two major unsuccessful challengers-Bill Bradley and John McCain-were each more successful in raising money through the Internet during the primary campaign than the eventual winners in their respective parties. $^{12}$

The Internet has also facilitated political organizational activity that has crossed national borders. The campaign against land mines was organized by e-mail. ${ }^{13}$ So was the opposition to the Multilateral Agreement on Investment (MAI), a proposal by countries belonging to the Organization for Economic Cooperation and Development (OECD) to relax restrictions on cross-border investment. ${ }^{14}$ The opposition from environmental and labor organizations in various developed countries was so intense that OECD member governments were

8. For an extensive discussion of the ways in which the Internet can improve the workings of government, see Jane Fountain, The Economic Impact of the Internet on the Government Sector, in THE ECONOMIC PROMISE OF THE INTERNET (Brookings Internet Task Force, forthcoming 2001).

9. Minimum Security Devices and Procedures and Bank Secrecy Act Compliance, 63 Fed. Reg. 67,529 (Dec. 7, 1998) (to be codified at 12 C.F.R. pt. 326).

10. Minimum Security Devices and Procedures and Bank Secrecy Act Compliance, 64 Fed. Reg. 14,845 (Mar. 29, 1999) (to be codified at 12 C.F.R. pt. 326).

11. Id.

12. John Mintz, McCain Camp Enjoys a Big Net Advantage, WASH. Post, Feb. 9, 2000, at A1.

13. Elaine Sciolino, It Turns Out That All Global Politics Is Local, N.Y. TIMES, Dec. 7, $1997, \S 4$, at 3.

14. Vanessa Houlder, Power Through Professionalism: Environment Campaigning, FIN. TIMES, Sept. 21, 2000, at 16 . 
forced to withdraw the proposal. ${ }^{15}$ Then there was the infamous protest in Seattle at the December 1999 ministerial meeting of the World Trade Organization, a meeting which was aimed at setting the next agenda for multilateral trade negotiations. Marches and sporadic violence disrupted the meetings and drew worldwide attention. Indeed, the protesters claimed credit for the failure of the ministerial meeting itself, although, in fact, governments had not formed a sufficient consensus on the outcome prior to meeting to have guaranteed a positive result. ${ }^{16}$ Nonetheless, the protests galvanized opposition to further trade liberalization, and this opposition remains in both the United States and in other (mostly developed) countries today.

Somewhat ironically, the use of the Internet-a global phenomenon-by the opponents of globalization highlights the potential power of the new technology. Never before have so many people in so many different places throughout the globe been able to organize so quickly and effectively to voice their views and to plan joint political activity. At the same time, however, the MAI and Seattle experiences indicate that the greater democracy unleashed by the Internet may not always be a force for good (although the protesters may certainly think so). There is a remarkable consensus among economists about the virtues of unrestricted trade-namely, that it will lead to lower prices, improved quality, and higher overall wages (due to enhanced productivity). ${ }^{17}$ These virtues will be promoted if trade liberalization proceeds, even in the face of opposition facilitated by the Internet.

The potential downside of Internet-based democracy may also be revealed if and when Internet voting becomes widespread. During the 2000 presidential primaries, the state of Arizona allowed voting by Internet, although it was challenged in court on the ground that uneven access among Arizona residents would unfairly tilt the electoral

15. Id.

16. James L. Kenworthy, The Unraveling of the Seattle Conference and the Future of the WTO, 5 GeO. PUB. Pol. REV. 103, 103-16 (Spring 2000), http://www.georgetown.edu/ publications/GPPR (on file with the Duke Law Journal); Interview with Jagdish Bhagwati, in Kentworthy, supra, http://www.georgetown.edu/publications/GPPR/52bhag.htm (on file with the Duke Law Journal); Interview with Robert Litan, in Kentworthy, supra, http://www.georgetown.edu/publications/GPPR/52litan.htm (on file with the Duke Law Journal).

17. I have discussed this subject at length, together with other colleagues, in GARY Burtless et Al., Globaphobia: Confronting Fears About Open Trade (1998). 
playing field toward those with computers and modems in their homes. ${ }^{18}$

A burgeoning future for widespread Internet voting is not hard to see. It is likely to arrive once there are assurances, first, that such voting is secure from hackers and, second, that there are reasonable opportunities for voters of all incomes to access the Internet. In fact, one early form of Internet "vote trading" was encouraged by supporters of Ralph Nader in the 2000 presidential election. ${ }^{19}$ Fearing charges that a vote for Nader could cost Vice President Gore the election, some Nader supporters encouraged voters in states likely to vote solidly for Gore to support Nader in return for promises by those Nader supporters in states where the race was tight to vote for Gore. Apparently some Nader voters actually completed their trades. ${ }^{20}$

Internet voting, like other things associated with the Internet, has its pluses and potential minuses. On the plus side, voting by Internet should increase participation rates, because it becomes so much easier to get to the polls. Indirect evidence of this effect can be found in extraordinarily high voter participation rates in Oregon-in excess of $80 \%$ - during the 2000 election, where voting was permitted only by mail. ${ }^{21}$ This experiment suggests that when people do not have to venture out of their homes to vote, they are more likely to do so.

A potential downside of the Internet in the political arena, however, is that the ease of organizing petition campaigns (where petitions may be signed with "digital signatures") over the Net may prompt much greater use of citizen-based initiatives of the type that have so been popular in California (even before the Internet was widely used). Once security is assured, there is no reason, at least in principle, why ballot initiatives cannot be developed virtually instantaneously, with the required number of digital signatures attained through e-mail campaigns.

To some, the prospect of voter-driven initiatives may be democracy at its best. "Electronic town meetings" are one of the things Ross

18. Ben White, Online Balloting: A Question of Fairness; Justice Department Challenges Arizona's Use of Voting by Computer in Primary, WASH. POST, Mar. 19, 2000, at A9.

19. Daniel J. Wakin, Vote Trading Via the Net a New Twist for Democracy, N.Y. TIMES, Oct. 31, 2000, at A20.

20. One site, VoteExchange.com, reported that it matched more than 6,000 Gore and Nader voters. Shailagh Murray, Nader's Cause Could Pay for His Spoiler Role: Consumer Advocate Would Make Enemies If Bush Wins Election, WALL ST. J., Nov. 9, 2000, at A17.

21. News Release, Oregon Office of the Secretary of State, Oregon Ranks Ninth in Voter Participation (Nov. 28, 2000), http://www.sos.state.or.us/executive/pressrel/112800.html (on file with the Duke Law Journal). 
Perot promised to bring to federal decisionmaking during his 1992 presidential campaign. To others, however, the notion that individuals will be able to click their position more easily on one of many issues $d u$ jour is not how our democracy is supposed to work. Instead, we live in a representative democracy, one that relies on political leaders elected by the people to make choices on tough issues. Elections are held for the purpose of choosing the agents to whom we delegate this power, not for the purpose of having individuals make important public decisions themselves. A system of cyber-voting coupled with electronically enabled ballot initiatives could easily degenerate into a "knee-jerk" democracy dominated by the whims and emotions of the electorate at particular points in time. In this sense, the future could resemble the very distant past: direct democracy in ancient Athens degenerated into mob rule, especially after the age of Pericles. ${ }^{22}$

For now, however, such worst-case outcomes are speculative at best. So far, at least, the Internet has promoted citizen participation in public life at many levels-local, national, and international-and thereby has helped reduce citizen alienation from what can often seem like abstract and distant decisionmaking processes. Improvements in process do not guarantee improvements in the results of decisions. To put it differently, information may be power, but history teaches that power can and often has been misused. We shall have to wait for some years before knowing whether the Internet will help or harm our political process.

\section{B. Economic Benefits}

The performance of the U.S. economy during the 1990s was extraordinary, especially during the last five years of the decade. During this period, the economy became more productive at an annual rate of about $3 \%$, or double the $1.5 \%$ rate of increase over the previous two decades. ${ }^{23}$ What is most remarkable about this achievement is

22. The Landmark ThuCydides: A Comprehensive Guide to the Peloponnesian

WAR 127-28 (Robert B. Strassler ed., Richard Crawley trans., Free Press 1996):

Pericles indeed, by his rank, ability, and known integrity, was enabled to exercise an independent control over the multitude-in short, to lead them instead of being led by them .... With his successors it was different. More on a level with one another, and each grasping at supremacy, they ended by committing even the conduct of state affairs to the whims of the multitude. This, as might have been expected in a great and sovereign state, produced a host of blunders, and amongst them the Sicilian expedition ....

23. ECONOMIC REPORT OF THE PRESIDENT 83 (Feb. 2000), http://w3.access.gpo.gov/eop (on file with the Duke Law Journal). 
that it came relatively late in the economic cycle. In past economic expansions, firms have found it harder to make their companies more productive as they dug deeper into the labor pool. ${ }^{24}$ This time around, productivity surged even as firms took on more workers-a totally unexpected development. The productivity boom in turn allowed firms to increase wages at a faster pace than in earlier years without threatening an acceleration of inflation.

There is a widespread consensus among economists that advances in high technology-especially computers, the prices of which have been falling at an annual clip of roughly $30 \%$ per year-have been a major reason why productivity has increased rapidly. ${ }^{25}$ The consensus breaks down over the contribution of computers to the economic performance of the rest of the economy. One of the leading skeptics, Robert Gordon of Northwestern University, finds no evidence of such "spillover effects" outside the manufacturing sector. ${ }^{26}$ Two former skeptics, Stephen Oliner and Dan Sichel, recently came to a different conclusion. They find statistical support for the notion that the diffusion of computer and information technologies has benefited firms throughout the economy. ${ }^{27}$ The President's Council of Economic Advisers essentially agrees. ${ }^{28}$ Somewhat in the middle are Dale Jorgenson and Kevin Stiroh, who agree with Gordon that productivity advances in the information technology (IT) sector have been important contributors to the improvement in overall productivity growth but who also find significant technological advances in the rest of the economy. ${ }^{29}$ They profess to be unable to sort out whether the productivity growth in the non-IT sector is due to spillovers from the advances in IT or from sources that are entirely independent of the IT revolution. ${ }^{30}$

The dispute about the impact of the high-tech revolution is perhaps most visible when it comes to the Internet. Enthusiasts who

24. Id. at 35 .

25. For a thorough discussion of the role of technology in contributing to recent U.S. economic performance, see Alan S. Blinder, The Internet and the New Economy, BRoOKINGS POL'Y BRIEF, No. 60 (2000).

26. Robert J. Gordon, Does The "New Economy" Measure Up to the Great Inventions of the Past?, 14 J. ECON. PERSP. 49, 57 (2000).

27. Stephen D. Oliner \& Daniel E. Sichel, The Resurgence of Growth in the Late 1990s: Is Information Technology the Story?, 14 J. ECON. PERSP. 3, 3-22 (2000).

28. ECONOMIC RePORT OF THE PRESIDENT, supra note 23, at 98, 112.

29. Dale W. Jorgenson \& Kevin J. Stiroh, Raising the Speed Limit: U.S. Economic Growth in the Information Age, in BROOKINGS PAPERS ON ECONOMIC ACTIVITY 125-211 (2000).

30. Id. 
work in the industry-often centered in Silicon Valley-tend to take it on faith that the Net is in the process of working a vast improvement in the performance of the U.S. economy. At the other extreme, skeptics such as Robert Gordon claim that although the Internet may appear significant to many today, in fact, other inventions such as the telegraph, the automobile, air conditioning, and electricity have had much greater impacts on the economy and the rest of society. ${ }^{31}$ So far, Federal Reserve Chairman Alan Greenspan-whose words and actions probably count the most—has sided with the optimists. He has suggested that the effect of all of the information technologies together (including the Internet) "could rival and arguably even surpass the impact the telegraph had prior to, and just after, the Civil War.",32

The truth is that we will not know for some years, perhaps a decade or more, what impact the information revolution, and the rapid growth of the Internet in particular, will have on long-term productivity, growth, inflation, and other measures of aggregate economic performance. The reason is that the use of the Internet for commercial activities-searches for the best prices and products and completion of transaction-is in its infancy. Although the latest estimates of e-commerce for the year 2000 (primarily business-to-business) range in the hundreds of billions of dollars, commercial activity using the Internet is widely expected to be counted in the trillions of dollars, here and worldwide, in just a few years. ${ }^{33}$

On theoretical grounds, there are reasons for believing that the growing use of the Internet for commercial activity will have a positive impact on productivity, at least during the time it takes for the best uses of the Net to diffuse throughout the economy. In principle, the Internet should enable firms to reduce the costs of carrying inventory, obtaining and managing necessary supplies, and dealing with customers. These are all impacts that, at least theoretically, can be measured. In addition, the Internet allows consumers greater choice in products and services-a positive impact that is difficult, if not impossible, to quantify - as well as the ability to find the least expensive and most suitable products and services.

31. Gordon, supra note 26, at 59-60.

32. Alan Greenspan, Improving Our Understanding of Productivity, THE REGION, June 2000 , at 9 .

33. U.S. DeP'T OF COMMERCE, Digital ECONOMY 2000, at 15-18 (2000), http://www.esa.doc.gov (on file with the Duke Law Journal). 
To ascertain how large these beneficial impacts might be, the Brookings Institution asked a group of academic experts to look out over at least the next five years and provide a plausible range of estimates for eight sectors of the U.S. economy: automobile manufacturing and sales, non-auto manufacturing, higher education and private-sector training, financial services, government, health care, retailing, and trucking. ${ }^{34}$ These eight sectors collectively account for more than $70 \%$ of annual gross domestic product (GDP). By their nature, the results are, at best, informed speculation about the possible impacts of the Internet in each of these sectors. Nonetheless, the findings are revealing. Broadly speaking, they suggest that ecommerce-primarily that between businesses (B2B)-should increase annual productivity growth by at least several tenths of a percent. This estimate does not mean that productivity growth will be even higher than the extraordinary 3\% annual growth achieved in recent years, but instead it is simply a projection that such growth is likely to be somewhat larger than it would otherwise be on account of networked computing. It is tempting to dismiss the importance of annual productivity growth improvements measured in tenths of a percent, but even a $0.3 \%$ improvement - which would be consistent with the kinds of projections that our study claims is possible-would, if cumulated over a ten-year period, translate into higher levels of GDP of perhaps 3\%-more than $\$ 1000$ in additional purchasing power for every man, woman, and child in the United States. ${ }^{35}$

\section{Social Benefits}

One of most widely advertised benefits of the Internet is that it is providing new "social" benefits through the creation of new cybercommunities. Unlike their physical counterparts, the cyber- or virtual communities are not defined by geographic proximity; instead, they are defined by interest. There are now chat rooms for seemingly anyone and anything. Many individuals somehow feel freer and more able to communicate when writing e-mails and notes to bulletin boards than when speaking directly to other individuals. People with life-threatening illnesses have found new support groups on the Net. Perhaps the most enthusiastic users of the new technology are aca-

34. The findings will be summarized in Robert E. LitAn \& Alice M. RivLin, Beyond THE DOT.COMS (forthcoming 2001).

35. This calculation is based on a per-capita income of approximately $\$ 35,000$ in 1999 and on figures in the ECONOMIC REPORT OF THE PRESIDENT, supra note 23. 
demic scholars, many of whom use the Internet daily to communicate with other experts in their fields, as well as to collaborate on articles or books in a fashion and at a speed that only a short time ago would have been unimaginable. ${ }^{36}$

It is not clear that all Internet-empowered communities are positive developments. The heavy use of chat rooms by day traders has been a mixed blessing, at best, for the stock market, driving many investors to trade on momentum rather than on the basis of fundamental values. Then there are the Internet hermits, who find it so comfortable to socialize on the Net that they neglect to develop or deepen real life relationships. Perhaps most worrisome are hate groups that have used the Internet to reach out to broader audiences and to recruit new members.

On balance, however, there appears to be a consensus that the community-building positives of the Net outweigh the negatives. In any event, it really does not matter. The Net is here and only getting bigger, and social relationships inevitably will adapt as it does.

\section{CONCERNS RAISED BY THE INTERNET}

As with all new technologies, the Internet has raised a series of concerns-some would say drawbacks-that are attracting increased attention among policymakers. In fact, the number of such concerns seems to proliferate as policymakers and citizens learn more about the impact that the Net is having. As a result, I cannot possibly address all of these issues. Instead I concentrate here on the implications of the Net in just four areas: privacy, intellectual property, taxation, and policies relating to broadband access to the Net. Each of these issues raises a common challenge. Should policymakers intervene now to mandate rules similar to those applicable in the "offline" world, or should they wait and see whether markets and technology will address the issue in a satisfactory manner?

Over time, three different answers to this question appear to have emerged. Initially, the widespread presumption among policymakers and many academic scholars was that the Internet should be kept as a "regulation-free" zone..$^{37}$ The Net was viewed as an ideal ex-

36. For a thorough discussion of how the Internet is leading to important social changes, see Andrew L. Shapiro, The Control Revolution: How the Internet Is Putting INDIVIDUALS IN CHARGE AND CHANGING THE WORLD WE KNOW (1999).

37. E.g., David R. Johnson \& David G. Post, And How Shall the Net Be Governed?: A Meditation on the Relative Virtues of Decentralized, Emergent Law, in COORDINATING THE 
ample of unplanned, private-sector innovation, the benefits of which could be curtailed, perhaps dramatically, by premature and ill-advised government intervention. Moreover, by its very nature, the Net could be impossible to regulate. An attempt by one jurisdiction to regulate content on the Net, for example, or to impose taxes on transactions completed over the Net, would simply prompt the host of the website in question to move its server to a different location. I candidly admit that when I began my own Internet-related policy research, I leaned heavily toward this libertarian view (although, as elaborated below, I have since altered my views somewhat). ${ }^{38}$ So did the Clinton administration, which offered a 1997 "White Paper" on Internet policy written by Ira Magaziner. The White Paper essentially argued that the private sector should take the lead on Internet issues, although some modest role for government was still envisioned (primarily to help close the so-called "digital divide"). ${ }^{39}$

As time has passed, and the issues that I am about to take up (and others) have attracted increased attention, a counterreaction to the libertarian approach has set in. Call it "interventionist" or "regulatory," but the essential claim is that the Internet is too important not to regulate. Professor Lawrence Lessig has become perhaps the best known and most articulate proponent of this view, although others have expressed similar ideas. ${ }^{40}$ In his book Code, Lessig outlines the core of his argument: that the rules on the Net so far have been written by software programmers (code writers), rather than legislators or regulators; that the code tends to be more restrictive than policy in the physical world; and that unless elected officials step in soon (Lessig has no confidence in judges getting things right), the code writers will triumph. ${ }^{41}$ Lessig is more pessimistic than are perhaps some other adherents of the regulatory model for the Internet,

INTERNET 62-91 (Brian Kahin \& James H. Keller eds., 1997); David G. Post, Governing Cyberspace, 43 WAYNE L. REV. 155, 157 (1996) (stating that "in the special circumstances of cyberspace, no choice of law rule-no algorithm we can apply to the set of potentially applicable rulesets defined in geographic terms - can provide... a sensible answer" to Internet regulation). Elsewhere, Johnson and Post argue for separate legal principles in "cyberspace." David R. Johnson \& David Post, Law and Borders-The Rise of Law in Cyberspace, 48 STAN. L. REV. 1367, 1367-1402 (1996).

38. ROBERT E. LitAN \& WiLliam NiskANEN, GOING Digital! 67-81 (1998).

39. Management of Internet Names and Addresses, 63 Fed. Reg. 31,741 (1998), http://www.ntia.doc.gov/ntiahome/domainname/6_5_98dns.htm (on file with the Duke Law Journal).

40. E.g., SHAPIRO, supra note 36, at 217-30 (asserting that a "balance between the market and government" is necessary).

41. LeSSIG, supra note 1, at 107-08. 
however, because he believes that legislative and regulatory gridlock prevent the right policies from trumping the rules of the code writers. $^{42}$

There is a third approach to Internet-related policy issues. It is more optimistic and more eclectic, and I shall label it "pragmatic" for lack of a better title. Under this view, to which I now subscribe, policy questions of the kind I shall treat next should and will be met through a combination of market and technological responses, as well as some governmental involvement in particular cases, often more to facilitate transition than as a permanent solution. The mix of markets and government will differ from issue to issue. In the long run market-based responses will generally dominate (as they often do) and either render a policy reaction unnecessary or induce policy to move in a particular direction. To be sure, there are dangers that premature or inconsistent and overlapping government involvement (from different jurisdictions) may produce errors-and specifically cause markets to veer off in different and less desirable directions than they otherwise would pursue - but I remain somewhat optimistic that this result will be avoided, or if not, that the damage will not be too great.

What about the libertarian claim that the Net has rendered governments powerless to regulate? That may well be true for certain smaller companies, nimble enough to avoid detection or to change locations at the drop of a hat. It is not likely to be the case with wellrecognized companies, such as Microsoft, AT\&T, IBM, and many other large companies that one could name. Such enterprises are likely to have too much stake in the physical world to pull up stakes and relocate simply out of a desire to avoid regulation of their Internet activities. These "elephants" of enterprise can be counted on to obey the law, whatever it is, unlike many of the "mice," whose activities can be difficult to detect and whose efforts to avoid regulation policymakers will have to live with. ${ }^{43}$

\section{A. Privacy}

One of the real "sleeper" political issues generated by the popularity of the Internet is privacy, or the ability of consumers to control

42. Id. at 213-21.

43. The distinction between "elephants" and "mice" on the Internet was first introduced, to my knowledge, in PETER SWIRE \& ROBERT E. LITAN, NONE OF YOUR BusINESS: WORLD Data Flows and the European Privacy Directive (1998). For further discussion, see generally Peter P. Swire, Of Elephants, Mice and Privacy: International Choice of Law and the Internet, 32 INT'L L. 991 (1998). 
what information about them others may be able to view or gain access to on the Net. Privacy advocates claim that on the Net, there is not much privacy at all. The mere act of visiting a website generally triggers the placement of "cookies" on an individual's computer." These cookies enable the website to welcome back a visitor, but they also allow the operators of that website to read from the cookie what other websites an individual has visited. This information may be sold to third parties or kept by the website itself to ascertain consumer preferences and target new product offerings more narrowly. Indeed, one of the more successful businesses on the Internet involves the use of cookie-generated information to target advertising to particular users. $^{45}$

Consumers are increasingly aware both that cookies exist and that Internet-based search engines allow virtually anyone to find out all kinds of personal information about virtually anybody else. It is, therefore, not surprising that in popular opinion polls an overwhelming majority of Americans consistently report that they are deterred from using the Internet more than they currently do because of privacy-related fears. ${ }^{46}$ For this reason, there appears to be significant public support for some kind of government regulation to restore consumers' privacy on the Net.

This is not the approach favored by many private-sector firms and opponents of government regulation. They argue that the market, supplemented by technology and perhaps by industry "selfregulation," will provide precisely the level of privacy that consumers desire. If consumers object to websites collecting data about them and possibly forwarding it to third parties, consumers can choose not to do business with the sponsors of those websites-just as consumers can make the same choice with companies doing business that way in the physical world. Furthermore, if consumers lack sufficient informa-

44. For a critique of cookies and other invasions of privacy made possible by the Internet, see Jeffrey Rosen, The Unwanted Gaze: The Destruction of Privacy in America $162-64(2000)$.

45. A newer method for collecting information from web users is the "web bug," or graphic image files that are embedded in web pages or e-mails but which are invisible to the user. Robert O'Harrow Jr., Fearing a Plague of 'Web Bugs'; Invisible Fact-Gathering Code Raises Privacy Concerns, WASH. POST, Nov. 13, 1999, at E1. The web bug sends back to its home server messages that contain, among other things, the Internet Protocol (IP) address of the computer that downloaded the bug, the time at which the page was viewed, and the identification number of any cookie that has been placed on the user's computer by that server. Id.

46. A well-known Harris survey has found that $92 \%$ of consumers are concerned and $67 \%$ are "very concerned" about misuse of their personal data online. John Schwartz, Opting In: A Privacy Paradox, WASH. PosT, Sept. 3, 2000, at H1, H4. 
tion to make these choices-as critics of the free-market approach freely point out-then others have incentives to develop technologies to provide that information and to enable consumers to act on it.

For example, the worldwide web consortium has produced a set of computer instructions, collected under the label P3P, that enable users to specify exactly how much personal information they will allow their computers to transmit to websites as they browse on the Net. The P3P instructions will alert users if a website does not meet their minimum criteria. As of mid-summer 2000, Microsoft was planning to introduce P3P in the next version of its browser. ${ }^{47}$ Similarly, in August 2000, Microsoft introduced software enabling users to detect whether third-party cookies-those deposited by web advertisers or their agents, for example-have been planted on their computers and, if so, to specify whether they wish to accept or reject them. ${ }^{48}$ The press also has played an important role-albeit in a sporadic fashion-in bringing to light information policies that consumers might find objectionable. For example, after the press reported that AOL planned to sell its subscriber information to third parties, the company abandoned the policy. ${ }^{49}$ Similarly, press reports that certain state transportation departments intended to sell driver's license photos to third parties prompted Colorado, Florida, and South Carolina to stop that practice as well. ${ }^{50}$

Then there is the private sector itself. The OnLine Privacy Alliance (OPA), a consortium of high-tech and "old economy" companies, agreed on a set of voluntary guidelines in 1998. The guidelines urged members to announce voluntarily their privacy policies-both on and off the Net-and to offer consumers a choice to opt out of having their information forwarded to third parties or used in any way other than that for which the data were originally collected. ${ }^{51}$ The OPA initiative is perhaps the best known of the "self regulatory" initiatives that were prompted by the threat of actual regulation. Advo-

47. Jerry Clausing, New Technology Is Aimed at Increasing Web Privacy, N.Y. TIMES, June 22, 2000, at C6.

48. The Microsoft "cookie detector" does not extend the same option to first-party cookies, however, or those planted by Microsoft's own websites. Third parties that collect information through cookies on behalf of advertisers such as DoubleClick have objected to this distinction. The author serves on the privacy board of DoubleClick.

49. Rajiv Chandrasekaran, AOL Cancels Plan for Telemarketing, WASH. Post, July 25, 1997, at G1.

50. Robert O’Harrow, Jr., Firm Changes Plan to Acquire Photos, Wash. Post, Nov. 12, 1999, at E3.

51. Keith Perine, The Persuader, The Industry StAndard, Nov. 13, 2000, at 154-70. 
cates of this approach claim that it illustrates how the market can help correct a problem without the need for actual government intervention.

Finally, there are a number of well-known services-such as TRUSTe and BBB Online-that will certify sites as having at least announced a privacy policy on the Net and will audit whether they adhere to those policies. Although these services do not require that choice in any of its forms (opt-in or opt-out) or that the right of access to information (another concern that privacy advocates have about the Net) be made available, they at least can help assure the public that what the sites say about their policies is true.

For all of these reasons, until early 2000, the official position of the federal government - at least as embodied in announcements by the Federal Trade Commission (FTC), which has become the de facto monitor and potential federal regulator of privacy on the Net-was that Net privacy was an issue better left to the market rather than to the government. ${ }^{52}$ There were two exceptions. In the case of material directed toward children under the age of thirteen, the FTC, under instructions from the Children's Online Privacy Protection Act of 1998 (section 1303), required websites to gain offline parental consent before seeking to obtain personal information from minors. ${ }^{53}$ In addition, websites that advertised a privacy policy—such as promising not to forward personal information to third parties without the user's consent-have to adhere to those policies; otherwise, they could be held in violation of section 5 of the Federal Trade Commission Act, which bans "unfair trade practices." 54

The FTC has since abandoned its moderate hands-off policy toward privacy on the Net. In large part, the Commission appears to have done so in response to two surveys of websites it conducted. The results of the first survey were announced in June 1998 and found that only $14 \%$ of websites had even posted a privacy policy. ${ }^{55}$ The second, follow-up study was released two years later. ${ }^{56}$ Although it showed

52. Privacy Online: Fair Information Practices in the Electronic Marketplace: A Report to Congress ii-iii (May 2000), http://www.ftc.gov/reports/privacy2000/privacy2000.pdf (on file with the Duke Law Journal) [hereinafter Fair Information Practice].

53. Pub. L. No. 105-277, 112 Stat. 2681 (1998).

54. In fact, the FTC has penalized the Geocities website for violating such a policy and sued the bankrupt online toy supplier Toysmart, Inc. for breaking its pledge not to sell its customer lists. Matt Richtel, Toysmart.com in Settlement with F.T.C., N.Y. TIMES, July 22, 2000, at C1.

55. FTC, PRIVACY ONLINE: A REPORT TO CONGRESS 27 (June 1998).

56. Fair Information Practice, supra note 52, at 3. 
dramatic improvement $-97 \%$ of the most popular sites and $62 \%$ of randomly surveyed sites reporting having a privacy policy-it nonetheless revealed that only $20 \%$ of all sites surveyed met FTC standards for adequate privacy. ${ }^{57}$ The poor compliance figures appear to have motivated the FTC in the summer of 2000 to request that Congress provide the agency with the legal authority to issue rules mandating a set of requirements relating to the collection and dissemination of personal information acquired from users of the Net. ${ }^{58}$

The FTC's embrace of government intervention represents a more general shift in the regulatory direction on privacy issues. Both major presidential candidates expressed sympathy with more federal activity in the privacy arena. Immediately after the election, it was reported that federal privacy legislation of some type-especially with respect to medical and financial records - was likely to be high on the congressional agenda in 2001. ${ }^{59}$ Although various federal and state statutes already protect certain kinds of financial information, Congress went further in 1999. As part of a sweeping overhaul of the nation's financial laws, Congress required that financial organizations provide consumers with notices of their privacy policies and, with certain exceptions, afford them the right to opt out of having their personal information forwarded to third parties. ${ }^{60}$ The Clinton administration wanted even greater protections. Specifically, it wanted an extension of the opt-out requirement for affiliates of financial institutions belonging to the same overall organization. Eventually, the administration accepted a compromise advocated by Senator Sarbanes and others that allows the states to enact tougher privacy protections (a problem I address below).

57. $I d$.

58. The Commission is not unanimous on this issue. Commissioner Orson Swindle has objected to government regulation of Net privacy. Dissenting Statement of Commissioner Orson Swindle 5, in Privacy Online: Fair Information Practices in the Electronic Marketplace-A Report to Congress (May 2000), http://www.ftc.gov/reports/privacy2000/swindledissent.pdf (on file with the Duke Law Journal).

59. Jim VandeHei \& David Rodgers, Election 2000: New Economy May Top Next Congress's Agenda, WALL ST. J., Nov. 8, 2000, at A17.

60. This legislation was the Financial Modernization Act of 1999, or what has come to be known as the Gramm-Leach-Bliley Act, named after the three main congressional committee chairmen who shepherded the bill through Congress. Gramm-Leach-Bliley Act, Pub. L. No. 106-102, 113 Stat. 1338 (1999). 
Nonetheless, during the summer of 2000 , the administration proposed that Congress adopt more sweeping privacy legislation. ${ }^{61}$ Its proposal not only included the opt-out requirement for financial affiliates but also required that all financial organizations collecting information about credit card purchases and medical data give consumers an opt-in right. ${ }^{62}$ An opt-in regime would prohibit the release of information unless consumers explicitly and affirmatively authorize it. In addition, the administration proposed giving consumers access to information collected about them, while allowing data holders to assess "reasonable" charges for doing so. Congress adjourned in October 2000 without taking up the proposal. Congress also considered but did not create a commission to examine a broad range of privacy issues and report back recommendations. ${ }^{63}$

Privacy on and off the Internet has become an important international issue as well, driven by the Privacy Directive of 1995 adopted by the European Union. ${ }^{64}$ In brief, beginning in 1998 the EU required its member states to establish comprehensive privacy regimes affording EU citizens broad opt-out rights and specific protections-enforced by centralized government agencies and private rights of action-for especially sensitive data. The directive defined especially sensitive data as information about an individual's religious beliefs, sexual orientation, medical history, and financial situation. Most significant from the standpoint of the United States, the directive threatened to impose the equivalent of a "data embargo" on the export of personal information about EU citizens to countries that did not, in the judgment of the EU, provide "adequate" protections of such information. Throughout much of the late 1990s, officials of the EU and the United States dickered back and forth about whether the patchwork of U.S. laws governing privacy would satisfy the adequacy test. If the EU or any of its member states had actually implemented the embargo, it could have had a significant adverse impact not only on ecommerce but also on commercial activities in general—and not just

61. Press Release, White House Office of the Press Secretary, The Clinton-Gore Plan to Enhance Consumers' Financial Privacy: Protecting Core Values in the Information Age (May 1, 2000) (on file with the Duke Law Journal).

62. Id.

63. The bills in Congress were championed in the Senate by Senators Fred Thompson and Herb Kohl and in the House of Representatives by Congressmen Asa Hutchison and James Moran. 49.

64. For an extensive discussion of this initiative, see SWIRE \& LITAN, supra note 43 , at 22- 
on U.S. companies doing business in Europe but on European firms doing business in the United States as well. ${ }^{65}$

In the end, the two sides agreed to what has been called a "safe harbor." ${ }^{\circ 6}$ The safe harbor allows U.S. companies doing business in Europe to export personal data on EU citizens, provided that they first satisfy the EU authorities that they have implemented data protections-notice, choice, and rights of access-that are essentially equivalent to the rights accorded those same individuals under EU law. Significantly for the United States, the EU agreed that the American combination of self-regulation and FTC enforcement for company violations of their self-proclaimed policies was sufficientwithout having to mimic the European Union's more comprehensive privacy regulatory system.

So what is the right approach to privacy on the Net? In my view, we are destined to live with some combination of markets, technology, and yes, some government intervention-the eclectic, and perhaps philosophically messy, but nonetheless pragmatic approach toward Internet policy that I outlined earlier. In fact, government intervention has already arrived in both the online and offline worlds. The main reason, I would submit, is that markets and technologies alone have not so far guaranteed the delivery of the level of protection that consumers want. This is because many consumers are still unaware of how the personal information they supply to a particular website may be used or do not know how to opt out of having such information forwarded to third parties. The law is moving in the direction of mandating notice, some means of choice, and perhaps the opportunity to access online databases to assure that personal information individuals may have supplied in the past is still correct.

The critical questions for policymakers are whether the mandates-when they come, either from federal or state legislators-will have unintended and undesirable consequences, and if so, whether those consequences can be avoided. The danger of premature and wrongly conceived regulation is of special concern in an environment-like that of the Internet-where technology is evolving rapidly. Policy should not get in the way of such technological evolution. Instead it should provide protections during the transition toward

65. Id. at 43 .

66. For a broad discussion of the EU Privacy Directive and the "safe harbor" proposal in particular, see Gregory Shaffer, Globalization and Social Protection: The Impact of EU and International Rules in the Ratcheting Up of U.S. Privacy Standards, 25 YALE J. INT'L L. 1, 70-88 (2000). 
technological solutions, if not accelerate the introduction and use of those solutions.

Some examples of the possible downside consequences of inappropriate privacy regulation and how those consequences so far have been avoided are worth noting. When individuals write checks from their bank accounts in order to make payments to merchants, they may not know that their bank has outsourced the check-processing function to a third party. Clearly, any rule that required consumers to opt in to, or allowed them to opt out of, authorizing the sharing of their personal banking information with such processors could add significant costs to banking operations. For this reason, although the Financial Modernization Act of 1999 gave consumers an opt-out right on information sharing, it provided an exception for third-party servicing of accounts and transfers necessary for joint marketing arrangements (provided that the third parties maintain the confidentiality of the information transferred).

A more general example is the importance of the free flow of financial information to companies that compile credit information on individuals and businesses. Credit reporting agencies allow banks and other lenders to check the creditworthiness of potential borrowers quickly and thus help ensure that the most creditworthy customers obtain the lowest cost of credit consistent with market conditions and are not charged the higher rates that are more appropriate for higher risk customers. Precisely because credit information is so important, Congress enacted the Fair Credit Reporting Act, which allows customers to obtain access to their credit files to ensure that there are no mistakes. ${ }^{67}$ Nonetheless, broader provisions aimed at restricting the transfer of financial information in the first place could impede the credit assessment process and thus either cause institutions to deny credit where it may be inappropriate to do so or prevent lenders from charging borrowers to whom they do extend credit interest rates that accurately reflect the risks involved.

Yet another example relates to information gathering of advertisement delivery services such as DoubleClick, which has been the target of criticism because it tracks the Internet activity of users who happen to click on websites that have asked DoubleClick to perform that function. What made many people especially nervous-and what triggered federal and state investigations-was a plan the company announced in early 2000 . The company intended to marry the data it

67. 15 U.S.C. $\$ 1681$ (1994). 
compiled online about the behavior of individuals on their computer with offline information obtained in a merger with a data marketer, Abacus. This combination would have enabled DoubleClick to link the computer user with his or her personal identity. Under the storm of protest that followed, the company backed away from that plan. Nonetheless, it is important not to overlook the fact that companies such as DoubleClick provide a service of real use to consumers. By aggregating all of the information it collects, DoubleClick and its competitors can assist their web-based clients to deliver targeted online advertisements to users, reducing costs and barriers to entry for the sites themselves and the hassle of junk advertisements for web users. Indeed, ad targeting is of greater importance than ever before because of declining "click-through" rates, which are now less than one half of one percent. ${ }^{68}$ Yet statutory or regulatory requirements, or even technologies such as Microsoft's "cookie alert" that discriminate against third-party cookies, can have the effect of increasing the costs of marketing, leading to increased costs for products and possibly reduced choice (to the extent some sites are forced off the Net) for consumers.

In short, privacy-related mandates can be costly, and those costs can show up in ways that may not be fully anticipated at the time they are imposed. In addition, privacy mandates-especially if they are written too prescriptively-could impede the development of even better technologies than those now available to give consumers greater power over their information without, at the same time, impeding the flow of information that now facilitates commerce. I personally do not believe that legislation of the type the Clinton administration proposed-an opt-out default for the transfer of most personal information, but an opt-in requirement for especially sensitive information, such as medical records and credit card spending patterns-would produce costs in excess of the benefits it promises in giving consumers more effective control over their personal data. I stress that this is a personal judgment, however, and I am not aware of any studies on the costs and benefits of such a mandate. Nonetheless, I believe there is a strong case for having at least some standard federal privacy standards that would preempt state legislation in this area. State legislation already has been invited by the Financial Mod-

68. Vijay D'Silva et al., Plastic Explosive, MCKInSEY Q., Fall 2000, at 43, 47, www.mckinseyquarterly.com/pdf/plex00.pdf (on file with the Duke Law Journal). The "clickthrough rate" measures the percentage of online users who see a banner ad and then click on it to see what information it conveys. Id. at 47. 
ernization Act in connection with financial services. ${ }^{69}$ A system of fifty different legal regimes for privacy is ill-suited to a marketplace, such as that created by the Internet, where geographic borders are essentially irrelevant. They can become relevant and excessively costly if the governments inside those borders begin erecting different legal structures for transactions depending on the location of the consumer or the provider.

In the long run, however, the cyber-libertarians are likely to have their day, too. Technology and markets ultimately should empower consumers to provide the amount of control over their personal data that they desire. The early technologies already mentioned, P3P and Microsoft's cookie alert, represent an initial move in this direction. ${ }^{70}$ So is the different approach pioneered by Zero Knowledge, which allows users to adopt up to five pseudonyms or "nyms" when surfing the Net. ${ }^{71}$ This feature provides anonymity but slows down response rates. Yet another approach is that offered by Lifeminders, which invites users to opt in to providing data about themselves in exchange for providing targeted services to them, such as reminders of birthdays and anniversaries of friends and relatives and easy-to-order gifts suitable for these occasions. ${ }^{72}$ Users who sign up with Lifeminders are told that the information they supply will be forwarded, without the users being personally identified, to various marketers. It is possible that a next step after Lifeminders will be companies (perhaps Lifeminders itself) that allow consumers easily to vary how much data they supply to websites in return for cash payments or discounts. Such a technology will ultimately establish a true market in personal information where the suppliers of the data-individuals themselvescontrol how much they want to supply and at what price. Indeed, in

69. In this connection, it is noteworthy that a number of major U.S. companies, including Intel, AOL, and Hewlett Packard, have announced support for national privacy legislation, marking a departure from the position of others in the private sector (reportedly including Microsoft, IBM, Yahoo, and Worldcom) that continue to advocate self-regulation as the appropriate answer. Drew Clark, Privacy: Industry Split over New Senate Privacy Bill, NAT'L J. TECH. DAILY, July 26, 2000 (PM edition); see also Amy Borrus, High Tech's Honeymoon on the Hill May Be About to End, BUS. WK., Nov. 13, 2000, at 69 (describing a divisive atmosphere developing on technology issues).

70. P3P has been criticized by some privacy advocates, however, for automating the transfer of information and thereby threatening privacy. Nathaniel Wice, Privacy Critics Slam Project Backed by White House, AOL and Microsoft, TIME DigITAL (June 23, 2000), at http://www.time.com/time/digital/daily/0,2822,48014,00.html (on file with the Duke Law Journal).

71. Jeffrey Rosen, The Eroded Self, N.Y. TIMES, Apr. 30, 2000, § 6, at 46.

72. John Schwartz, 'Opting In': A Privacy Paradox, WASH. Post, Sept. 3, 2000, at H1. 
principle, there is no reason why some individuals should be prevented from allowing data about them to be connected with their identities, as long as they are aware of that connection, and presumably are compensated in some fashion (if they so desire) for being willing to allow such transfers.

To be sure, there will be those who will object to the trafficking in information, asserting that some things-like data-money cannot or should not buy. These arguments are akin to those who claimed some time back that trading in emissions should be prohibited because no price should be put on pollution. Yet markets have now been created in emissions permits, and the results have been beneficial to the environment and have reduced costs at the same time. ${ }^{73}$ I strongly suspect that the same will happen with information flows. As consumers become more widely aware that information about them is valuable - and they certainly will with all of the attention focused on this issue-they will increasingly assert control over it and ask that policymakers let them decide for themselves whether to keep it or sell it. In the meantime, however, until a higher awareness level is achieved and the technologies are in place for enabling a fair market in information, modest additional regulatory protections are appropriate and are likely, in at least some form, to be adopted.

\section{B. Intellectual Property}

To some producers of traditional "content"-books, records, and movies-the advent of the Internet must have seemed like the worst of nightmares. Here was a technology that appeared to be capable of allowing its users to copy original material, without compensating the creator, from a digital file located on a diskette or hard disk of some computer or server and then to transmit it or make it available instantly, not just to one or few other viewers, but to everyone else connected to the Internet.

Not surprisingly, the content industry quickly fought back, persuading Congress to enact the Digital Millennium Copyright Act of 1998, which, among other things, made it a crime to facilitate the circumvention of lawful copyrights. ${ }^{74}$ In addition, many content produc-

73. See Richard Schmalensee et al., An Interim Evaluation of Sulfur Dioxide Emissions Trading, 12 J. ECON. PERSP. 53, 53-68 (1998).

74. Pub. L. No. 105-304, 112 Stat. 2863-65 (1998). Among other things, the Act prohibits the manufacture, importation, or distribution of "any technology, product, service, device, component, or part" that is "primarily designed or produced for the purpose of circumventing a 
ers used technology to prevent access to copyrighted material unless users paid for it. Lawrence Lessig argued that the technology-or "code," as he put it-would be stronger than law itself. ${ }^{75}$ If users had to pay every time they wanted to access something on the Net, there would be no "fair use." Furthermore, assuming the technology would be effective that long, it promised protection forever, not just for the twenty years of a patent or the statutory life of a copyright (life of the creator plus seventy years). ${ }^{76}$ If Lessig were right, the libertarian approach to the Internet would become its own nightmare, affording much greater monopoly power to content creators than Congress-or the Constitution, for that matter-ever envisioned.

If there is one feature of the Internet revolution that has proved constant since its beginning, it is its unpredictability. At the time the Internet was launched in the late 1960 s-as a vehicle for data communications between universities and the government-few, if any, foresaw the development a little more than two decades later of the browser, which would launch e-commerce. Even Bill Gates has admitted that his company initially missed the importance of the Internet. Microsoft turned completely around in the mid-1990s to embrace the Net-so much so that its tactics eventually became central targets in the Justice Department's antitrust lawsuit against the company. ${ }^{77} \mathrm{Al}-$ most immediately after Lessig's book Code was published, the filesharing movement on the Internet was launched with the development of Napster, which has allowed tens of millions of teenagers and adults to swap digital sound recordings of major artists for free by locating copies identified on Napster's central server. At this writing, Napster's continued legal status is unclear after challenge by seventeen record companies (supported by the Recording Industry Association of America) ${ }^{78}$ Even if Napster is eventually shut down, file

technological measure that effectively controls access to a work protected under this title." $I d$. at 2864.

75. LESSIG, supra note 1, at 122-41.

76. Id. at $135-36$

77. Judge Thomas Penfield Jackson found that Microsoft had violated both sections 1 and 2 of the Sherman Act by effectively requiring its customers to deal exclusively with Microsoft, attempting to divide markets, and evidencing unlawful intent in bundling the company's operating system (Windows) with its browser (Internet Explorer). United States v. Microsoft Corp., 84 F. Supp. 2d 9, 12, 50 (D.D.C. 1999). At this writing, the case is on appeal before the United State Court of Appeals for the District of Columbia.

78. The lawsuit was filed in the U.S. District Court for the Northern District of California alleging, among other things, that by maintaining a central listing of all sound recordings available through the service, the company was facilitating circumvention of the copyright laws in violation of the Digital Millennium Copyright Act. See A\&M Records, Inc. v. Napster, Inc., 114 
sharing - which no doubt will be extended to copies of movies, books, magazines, and software-is like a cat out of the bag. File-sharing programs such as Gnutella, Scour Exchange, Imesh, and Freenet, which allow users to trade digital recordings without providing a directory on a central server, almost surely will continue to exist and be difficult, if not impossible, to halt through legal means. More importantly, although the other file-exchange programs are more difficult to use than Napster, it is likely that they will be refined to be made more user-friendly. Furthermore, Napster itself could be cloned offshore and could be difficult to halt through legal means. This remains true even now that Napster has announced a venture with Bertelsmann that would create a paid subscription service for music. ${ }^{79}$

In short, the technology that Lessig feared would override copyright law instead may now be in the process of undermining it. The only reason for the qualification is that these file-sharing programs so far tend to be much more difficult to use than Napster. ${ }^{80}$ The critical question for the entire "content industry"-sound and video recordings, books, and software publication-is whether some new technology will be developed that will enable the providers to transmit securely any of these forms of content over the Internet without fear of copying.

As I write this, several such efforts are under way, although their outcomes are uncertain. Perhaps the best known is the Secure Digital Music Initiative (SDMI), a collaborative initiative pursued by the major record companies and others to develop a secure way of delivering sound recordings over the Net in a way that they cannot be subsequently copied and transmitted to other (non-paying) users. ${ }^{81}$ Presumably, others are working independently on means of encrypting sound recordings (and other digital files) to accomplish the same objective. A key problem with any one of these approaches is that even

F. Supp.2d 896 (N.D. Cal. 2000), aff'd in part, rev'd in part, 2001 WL 115033 (9th Cir. 2001). One of Napster's defenses is that it is an Internet service provider protected under the 1998 Digital Millennium Copyright Act and that, like a VCR, it is used for "substantial non-infringing uses" and thus is legally permissible. Id. at 912 . Just before this Essay went to press, the United States Court of Appeals for the Ninth Circuit affirmed the district court's preliminary injunction against Napster. At this writing, Napster is reportedly still weighing its options. A Win for Intellectual Property, N.Y. TIMES, Feb. 14, 2001, at A30.

79. Lee Gomes et al., Bertelsmann, Napster Agree on Service, WALL ST. J., Nov. 1, 2000, at A3 (describing the cease-fire between Bertelsmann AG and Napster).

80. Timothy J. Mullaney, You Call This a Revolution?, Bus. WK., Sept. 18, 2000, at 28.

81. Cary Sherman, Music on the Internet: A New World Is Waiting, BROOKINGS REV., Winter 2001 , at 35 
if the digital files are initially encrypted, they must be decrypted in order to be read or played. At that point, the decrypted versions are subject to copy and transfer. ${ }^{82}$

An alternative approach for protecting the files is for hardware manufactures to develop new devices for reading or playing content that can read only certain types of files, which are not then subject to further copying. This may work reasonably well for software and books but perhaps less well for audio or video recordings, which can be manually copied after they are shown and then digitized for further copying and transfer (although quality would be degraded in the process).

What if technology cannot provide the answer? Might it not be possible to enact new laws making file sharing of copyrighted material illegal and to back the laws with a powerful enforcement effort? In theory, such an approach could be tried. At least in my view, however, it is highly doubtful that Americans would tolerate for very long, if at all, the police raiding homes and arresting teenagers for copying music or movies. A potentially more promising enforcement approach would be to impose liability on browsers and Internet Service Providers (ISPs) for allowing all types of file-exchange programs to work on their services and/or software. Although it is not clear that such a solution is even technically feasible, it would surely be strongly contested by the ISPs in the political arena.

The problems with each of the foregoing concepts have prompted some to think about developing a new business model for delivering copyrighted works. One commonly mentioned approach is for the recording companies to provide music on a subscription basis, as the Napster-Bertelsmann deal promises. ${ }^{83}$ The premise behind this idea seems to be that if the subscription price is low enough, users will obey the law and pay the money rather than continue to exchange files for free. I am skeptical that this is the case, and I am not alone.

82. For an excellent popular guide to these and other problems posed for copyright by peer-to-peer computing and file sharing, see Charles C. Mann, The Heavenly Jukebox, ATLANTIC, Sept. 2000, at 39-59. Some are more optimistic that the encryption problem will be solved. E.g., Don Clark, Napster Alliance Boosts Prospects for Encryption, WALL ST. J., Nov. 2, 2000 , at B1.

83. Sherman, supra note 81 , at 36 .

84. E.g., Dennis K. Berman, With Technology Like This, Who Needs Napster?, BUS. WK., Aug. 14, 2000, at 121 (commenting that it might be difficult for the music and film industries to create subscription-based services when Napster and Gnutella offer content for free). 
On the other hand, maybe the market would prove me (and the other skeptics) wrong. ${ }^{85}$

Another model, suggested by Hal Varian, is that corporations could sponsor sound recordings that help identify the music with their companies. ${ }^{86}$ The virtue of this approach is that it does not depend on compliance with the copyright laws. Corporations would not care if the recordings were copied and spread like a virus over the Internet. To the contrary, they would welcome the publicity to the extent it promoted their particular brand. The downside is that there are certainly limits to how many companies would want to get into the recording business. This means it is likely that fewer songs would be produced and publicized if this were the only way for recording artists to reach the masses and still be compensated in some fashion.

Another approach is for performers to return to the prerecording world and realize the bulk of their income through personal performances rather than through recordings. The Internet would enhance their appearance fees to the extent that it enabled more people to copy and trade digital files containing their songs. In this sense, the Internet would return the music industry to its prerecording roots, when performers earned their living through live performances-but with the vastly augmented power of the Internet to enhance their fame. Such a personal performance model cannot rescue the e-book, software, or videos from the royalty-destroying features of file sharing in the absence of new technology. Accordingly, peer-to-peer computing may prevent the emergence of an economically viable way of distributing these other forms of content over the Internet.

Finally, it is conceivable that the concern about file sharing, at least with respect to the music industry, has been overdone. Perhaps file-sharing services such as Napster, Gnutella, and Freenet actually promote the sales of CDs because they familiarize many people with particular songs quickly. It might be the case that the new listeners are then induced to go out and buy CDs that sound better to them when played on recorders than music played through computers. Of course, critics would respond that as long as something like Napster

85. One poll of Napster-using college students indicates that $68 \%$ of them would be willing to pay as much as $\$ 15$ per month for a music subscription service. Spencer Ante, Napster: Tune In, Turn On, Pay Up, Bus. WK., Nov. 13, 2000, at 52. In addition, some technologists are optimistic that the Napster-Bertelsmann combination can develop software that will prevent unlawful file sharing. $I d$.

86. Mann, supra note 82, at 54 . 
exists in its current form, consumers have no incentive to buy new CDs because it is so easy to "burn" customized CDs from the files downloaded for free off the Net. The plaintiffs in the Napster lawsuit also claim that the services depress the sales of recordings and point to an alleged drop in CD sales in the college towns where Napster first became popular. ${ }^{87}$ At this point, it is not clear who is correct. ${ }^{88}$

In the end, the libertarian model seems to be winning as applied to copyright and the Internet. So far, technology has triumphed over the law. As with so much else about the Internet, whether it will continue to do so cannot be predicted easily.

\section{Taxation}

Sales taxes are a third area of policy in which the Internet has provoked deep controversy. As anyone who has bought something over the Internet knows, online merchants tend to set up shop in states that do not levy sales taxes. Under court-established nexus standards, these merchants are prohibited from collecting use taxes (roughly the equivalent of sales taxes on out-of-state purchases) that consumers often owe, but generally do not pay, to the states in which they reside. ${ }^{89}$ The nexus standards, which were first applied to mailorder merchants, require out-of-state merchants to have a physical presence in the consumer's state before they can be required to collect such taxes. The Supreme Court has held that otherwise it would be an undue burden on interstate commerce to require all vendors to collect such taxes. ${ }^{90}$

For all cyber-libertarians, the arrival of the Internet has been a blessing, for it constrains and ultimately may inhibit state and local jurisdictions. For these local administrations, whether they be Democrats or Republicans, the Internet is a nightmare for the same reason.

87. For an example of such a claim, see Michael Fine, Soundscan Study on Napster Use and Loss of Sales 1-2 (June 12, 2000), Recording Industry Association of America, http://www.riaa.com/napster_legal.cfm (on file with the Duke Law Journal).

88. There may be a distinct generational difference in the willingness of Napster's users to pay for CDs. In particular, baby boomers who have been accustomed to paying for music all of their lives may feel more compulsion to pay for a CD after locating a song through Napster than teenagers or those in their twenties. Anna Wilde Mathews, Web Music Isn't Just for Kids, WALL ST. J., Sept. 26, 2000, at B1.

89. See Quill v. North Dakota, 504 U.S. 298, 313 (1992) (stating that nexus requirements "limit the reach of state taxing authority so as to ensure that state taxation does not unduly burden interstate commerce").

90. Id.; see also Nat'l Bellas Hess, Inc. v. Dep't of Revenue of Ill., 386 U.S. 753, 759 (1967) (invalidating an Illinois use tax statute as an undue burden on interstate commerce). 
Not only does it threaten to undermine one of the most important sources of state and local government revenue, but it also gives what certainly looks like an unfair advantage to online retailers.

For now, Congress has imposed a moratorium on Internetspecific taxes that is set to expire on October 1, 2001. ${ }^{91}$ In 1999, Congress also established a Commission on Internet Taxation, which was chaired by Governor James Gilmore of Virginia and charged with developing recommendations supported by at least two-thirds of the members. The commission was unable to do so, however, in its completed report in March of 2000. Nonetheless, a majority supported a five-year extension of the Internet-specific tax moratorium and recommended that digital products downloaded over the Internet (such as software, books, or music) not be subject to sales tax. ${ }^{92}$

So far, at least, there is no crisis at hand. In the first government report on Internet commerce, the Bureau of the Census put the total value of retail e-commerce in the fourth quarter of 1999 at a little more than $\$ 5$ billion, which translates into an annual volume of roughly $\$ 20$ billion. At this rate, e-commerce represents only $0.64 \%$ of retail sales. ${ }^{93}$ Taking account of various exemptions to the sales tax, the most reliable recent estimate indicates that e-commerce is costing states and local governments throughout the country only a little more than $\$ 400$ million, or less than $0.05 \%$ of their revenue..$^{94}$ This is at a time when state and local governments collectively have been running large surpluses. ${ }^{95}$ Even if e-commerce grows rapidly in the years ahead, as long as the overall economy stays healthy, state and local governments as a whole almost certainly will continue to reap large surpluses.

Nonetheless, there is a legitimate fairness issue posed by the effective tax-free status of goods and services sold over the Net versus in-person sales in the physical world that are subject to state or local taxes in most jurisdictions. Moreover, it is certainly possible that one day the revenue loss will be significant, requiring state and local gov-

91. VandeHei \& Rodgers, supra note 59, at A17.

92. Advisory Commission on Electronic Commerce, Report to Congress 19 (Apr. 2000), http://www.ecommercecommission.org/acec_report.pdf (on file with the Duke Law Journal).

93. U.S. DEP'T OF COMMERCE, supra note 33, at 9.

94. Austan Goolsbee \& Jonathan Zittrain, Evaluating the Costs and Benefits of Taxing Internet Commerce, NAT'L TAX J., Sept. 1999, at 417.

95. The total surplus enjoyed by state and local governments was $\$ 41.7$ billion in 1998 and $\$ 50$ billion in 1999. ECONOMIC REPORT OF THE PRESIDENT 371 (Feb. 2001), http://w3.access.gpo.gov/eop (on file with the Duke Law Journal). 
ernments and/or the federal government to respond. What are the basic options?

One possible outcome is for technology to come to the rescue, in the form of easy-to-use software for calculating use taxes. With the development of such software, which presumably could be kept up to date despite the complexity and diversity of sales tax structures in thousands of state and local jurisdictions, it presumably would no longer be a significant burden on interstate commerce for online vendors to collect use taxes owed by their customers. Having the software available, however, does not mean that it would be used. Congress most likely would have to enact legislation, after appropriate hearings and fact-finding establishing the low cost of the software, mandating that all vendors collect use taxes. Presumably, such a law would be challenged in court. With the findings of fact in place, there would be a strong case that changes in technology since the Supreme Court last spoke on the matter (in the Quill decision in 1992) war- $^{96}$ war rant modification or elimination of the nexus requirement. Collection of use taxes no longer would seem to represent an undue burden on interstate commerce.

A variation of the vendor mandate, ostensibly to reduce the costs imposed on the vendors of collecting the state and local taxes, would be to give that function to a "trusted third party" such as a credit card company or a new governmental or quasi-governmental organization. The key objection to this idea, however, is that unlike any individual vendor, which would maintain customer records only for its sales, a trusted third party would have records of all of the online (and possibly mail-order) purchases by customers. ${ }^{97}$ Such an organization would pose a much greater threat to customer privacy, especially if its records could be easily obtained under court order, than would be the case if individual vendors each remitted the taxes owed. For this reason alone, the trusted third party "solution" seems nonviable.

Another possible outcome is that states and localities will harmonize their sales tax structures so that the complexities now present would narrow or disappear. Jurisdictions could still charge different tax rates, but eliminating or reducing differences in tax bases would

96. Quill Corp. v. North Dakota, 504 U.S. 298, 313 (1992)

97. See MANN ET AL., supra note 1, at 92-93 ("[A]n individual's identity and purchasing habits would be in the hands of a TTP [trusted third party].").

98. For other objections to the concept, especially as applied in an international context, see $i d$. 
also undermine the argument that collection of use taxes on out-ofstate consumers represents an undue burden on interstate commerce. In fact, to the extent that harmonization occurs, it would make the job of software developers that much easier. If tax structures are harmonized, it may also be politically easier for Congress to enact legislation mandating the collection of use taxes by online and mail-order merchants.

Still, there are major political hurdles to both the technology and harmonization solutions to the sales tax problem posed by ecommerce. It will be difficult, to say the least, for the large number of taxing jurisdictions-in excess of 30,000-to obtain agreement on anything, let alone on something as complex as some of the sales and use taxes that many of them now levy. Moreover, any congressional mandate would be sure to rouse the ire of the online and mail-order vendor communities, and it would be portrayed by other opponents as the equivalent of a national sales tax. Supporters, including many Main Street small businesses, would respond that requiring vendors to collect use taxes is not only fair but simply ensures that use taxes not now being paid are in fact collected.

My own view is that Congress will be reluctant to impose a national mandate to collect use taxes as long as states and localities are running large surpluses. Even if surpluses dwindle or turn to deficits, the natural response of local and state jurisdictions will not be to wait for Congress to act but instead to take matters into their own hands and turn to other sources of revenue, most likely income-based taxes. Such an outcome is hardly undesirable. As it is, given their many exemptions, sales taxes reach only about $40 \%$ of total consumption and are not as progressive as income taxes. ${ }^{99}$

In the end, cyber-libertarians may win the battle but lose the war on taxes. Although our political system may not be able to muster the support for nationalizing the sales tax, the need for local and state government revenue will remain. The net result is likely to be a gradual replacement of the sales tax with income taxes. The Internet will not cause the government to wither away but rather to reinvent itself so that it can continue to deliver the services that citizens have come to expect and demand.

99. Hal R. Varian, Taxation of Electronic Commerce, Internet Policy Institute, at http://www.internetpolicy.org/briefing/4_00_story.html (Apr. 2000) (on file with the Duke Law Journal). 


\section{Broadband Access}

One of the great virtues of the Internet is that, at least so far, it has been inexpensive for anyone to get on. This is largely because of intense competition among ISPs and flat-rate pricing (unlike in Europe and other countries). Current law mandates that ISPs lease facilities from the telephone companies for a good reason: the Regional Bell Operating Companies (RBOCs) whose lines are leased have a monopoly in providing access to the home over (copper) telephone wires. ${ }^{100}$ The best known ISP is American Online, which bundles its own content with the ISP service for which it charges residential customers approximately $\$ 22$ per month (at this writing). Some ISPs, such as Juno, are free (and are supported by advertisers).

The next phase of Internet development is tied to the development of higher-speed, "broadband" Internet services (at speeds exceeding one megabit, in contrast to most current modems, which operate at fifty-six kilobits, or kbps). Broadband technologies include delivery of data through coaxial cable lines, conventional copper wires upgraded through DSL technology, and, eventually, through wireless devices (especially once advanced third-generation standards, such 3G, are rolled out) or satellite technology. As of mid-year 2000, approximately 4.3 million homes-only a small fraction of households - had some kind of broadband service. ${ }^{101}$

One of the more controversial policy questions associated with the rollout of broadband is whether any or all of the providers should be required to lease their facilities to other ISPs in the same way that ISPs are now guaranteed access over telephone lines. ${ }^{102}$ This issue bears strong similarities to others that have just been addressed. Should policymakers intervene in a nascent market and impose a regulatory regime? Or should they wait to see if competitive problems with cable broadband materialize, and act only if they do? Should the same regulatory regime apply to all broadband providers-specifically to cable and the telephone companies-or should a

100. The Telecommunications Act of 1996, 47 U.S.C. $\S 201$ (1994), was enacted in part to facilitate competition in local telecommunications services. Since the Act's passage, some competition has emerged, primarily from Competitive Local Exchange Carriers (CLECs).

101. John R. Wilkie, Cable-Line Accord Is near in AOL Case, WALL ST. J., Nov. 6, 2000, at A3, A16.

102. Robert W. Crandall \& Jerry A. Hausman, Competition in U.S. Telecommunications Services: Effects of 1996 Legislation, in DEREgUlation OF NETWORK INDUSTRIES: What's NEXT? 74, 80-82 (Sam Peltzman \& Clifford Winston eds., 2000), http://www.aei.brookings.org/ publications/books/deregulation.pdf (on file with the Duke Law Journal). 
special "open access" policy apply only to DSL provided by the RBOCs? Can any response be effective?

The open-access debate first surfaced on the political scene shortly after AT\&T purchased two of the nation's largest cable systems, TCI and Media One, and promised to develop a package of Internet, television, and telephone service through the coaxial cable wires of each system. American Online (AOL) objected soon thereafter, fearing that AOL either would not be carried at all on the new broadband networks or would be disadvantaged in pricing or some other way. After all, AT\&T then had an interest in its own competing Internet portal service, Excite@Home. AOL's complaints had resonance if for no other reason than that AT\&T was broken up in the early 1980s - after a lengthy federal antitrust investigation and lawsuit-precisely because it had used its monopoly control over local telephone service to frustrate interconnection by competing longdistance providers, most notably MCI. If monopoly cable companies also carried their own content-including an Internet portal servicethen they arguably would have the same incentives and ability to discriminate against competing content providers and ISPs.

AOL pleaded its case before the Federal Communications Commission as well as before numerous local jurisdictions, which had authority over local cable franchises and were therefore required to approve the transfer of those franchises from TCI and Media One, respectively, to AT\&T. Although the FCC rejected AOL's complaints, AOL had more success with two localities-Portland, Oregon, and Broward County in Florida. Each imposed an "open access" requirement on AT\&T as a condition to approving the transfer of the cable franchise. ${ }^{103}$

The FCC opposed these local ordinances on both legal and substantive grounds. ${ }^{104}$ Legally, the FCC claimed that it had exclusive jurisdiction over cable issues and that a series of local ordinances would make it impossible to have a national policy on the subject. In short, the FCC demanded the right of federal preemption.

As a matter of policy, the FCC initially agreed with AT\&T and various academic scholars that regulatory intervention requiring AT\&T or any other would-be broadband service provider to provide

103. John Schwartz, Open-Access Online Fight Escalates, WASH. Post, July 28, 1999, at E1.

104. Brief of Amicus Curiae Federal Communications Commission, AT\&T Corp. v. City of Portland, No. 99-35,609 (9th Cir. June 22, 2000), http://techlawjournal.com/courts/portland/ $19990816 \mathrm{fcc} . \mathrm{htm}$ (on file with the Duke Law Journal). 
equivalent access to other service providers was highly premature. ${ }^{105}$ The broadband market was in its infancy. No one at that point (199899 ), or for that matter even today, could or can predict with confidence that broadband cable will so dominate the broadband business that it will have monopoly power. Cable faced then, and still faces today, strong competition from DSL, whether provided by the RBOCs or various independents, and potentially from wireless and satellite services. Ordinarily, government regulation designed to thwart the exercise of monopoly is not imposed unless and until a monopoly actually exists (as occurred in the past in the telephone and electricity markets). Then and today, no such monopoly exists in broadband.

The FCC was concerned about premature regulation for another important reason. Imposing open access on cable would allow other providers to "free ride" on AT\&T's planned investment in the new cable broadband service. This would diminish AT\&T's incentives to roll out an attractive combination of telecommunications services that would compete directly against the RBOCs. This last point was especially important to the FCC because of its desire to generate meaningful competition in voice telephony at the local level.

For all these reasons, the FCC joined with AT\&T in challenging the Portland ordinance in federal court. In early 2000, the FCC and AT\&T were largely successful when a panel of the U.S. Court of Appeals for the Ninth Circuit agreed that the FCC had exclusive jurisdiction. ${ }^{106}$ At the same time, the court also held that cable broadband was a "telecommunications service" of the type that the RBOCs currently provide. ${ }^{107}$ This was important because it is the fact that the RBOCs offer a "telecommunications service" that makes them subject to FCC rules (one of which is an open access requirement for ISPs). The decision, therefore, effectively invited the FCC to resolve whether it was time to apply the same policy toward cable broadband. In late September 2000, the FCC opened a broad inquiry into the subject of broadband access policy, but it is not expected to act until at least some time in 2001 . $^{108}$

This brings us back squarely to the policy issues. The fact remains that although it is widely hailed as the future of the Internet,

105. Id.

106. AT\&T Corp. v. City of Portland, 216 F.3d 871, 879-80 (9th Cir. 2000).

107. Id. at 878 .

108. The FCC opened its Notice of Inquiry on September 28, 2000. Federal Communications Commission Notice of Inquiry, In re Inquiry Concerning High-Speed Access to the Internet Over Cable and Other Facilities, GN Docket No. 00-185, FCC 00-355 (Sept. 28, 2000). 
broadband is still a very new technology. It is also the case that no one can predict with confidence which, if any, of the various means of delivering it will ever dominate the market. Take AT\&T itself. At the time of its two cable mergers, there was widespread expectation that AT\&T had the potential winning formula in the broadband race. Yet by the summer of 2000, AT\&T's cable units were giving away the service for limited times in some locations to jump-start the market because the roll out of the service was behind the company's announced schedule. In late October, after the company's stock price had fallen by roughly two-thirds from early in the summer, AT\&T announced that it was splitting itself into four pieces, one of which would offer broadband services. All these events cast a pall over cable broadband service, which, although it was the most popular way of delivering high-speed access in mid-year 2000, was still growing at a far slower rate than DSL. ${ }^{109}$

Of course, DSL is not without its own problems. Given the limits of the technology, DSL service can work only for customers who are located within about three miles of a central switch. ${ }^{110}$ This leaves out many residential customers. In addition, complaints have been widespread about the service interruptions and problems of DSL installers associated with the service. Finally, although wireless Internet services are taking off in Europe and Japan, they are in their infancy in this country.

In short, the broadband market is very much in flux. So is the entire communications market. Some time after the AT\&T cable mergers, AOL announced its acquisition of Time Warner, one of the largest content companies in the world (with its television, music, publishing and magazine businesses), as well as the owner of cable systems in parts of the country. Immediately after the merger, AOL changed its tune on the mandating of open access for cable. ${ }^{11}$ Now AOL said that although it planned to provide access to other ISPs voluntarily, it was better for the market to handle the issue than for government to interfere with a mandate. ${ }^{112}$ The Federal Trade Com-

109. Wilkie, supra note 101. Of the 4.3 million broadband lines in service in mid-year 2000, 2.2 million were cable, and DSL stood at about 1 million. DSL service was up $157 \%$ during the first six months of the year, far outdistancing cable's growth of $59 \%$ during the same period. Id.

110. Peter S. Goodman, Dishing Up a New Link to the Internet, WASH. Post, Nov. 6, 2000, at A1.

111. Ariana Eunjung Cha \& Peter S. Goodman, AOL, Time Warner Try to Allay Fears, WASH. POST, Mar. 1, 2000, at E1.

112. Id. AT\&T, too, said that it would allow access by other ISPs once its contract with Excite expired in 2002. Any open access conditions imposed on AOL-Time Warner need not be 
mission (and implicitly the FCC) called AOL's bluff, insisting that AOL-Time Warner carry at least three other ISPs on their cable lines as a condition for approving the merger. ${ }^{113}$

The open access conditions imposed on AOL-Time Warner do not necessarily mean that all cable providers should be subject to the same requirement-an issue which is at the heart of the FCC's generic inquiry into broadband policy. The fact remains that there is a great deal of uncertainty in the broadband market. The AOL-Time Warner marriage differs from the AT\&T combinations with Media One and TCI, respectively, in that no other ISP (including AT\&T) comes close to AOL's customer base of nearly twenty-five million. ${ }^{114}$ Furthermore, AT\&T was required, as a condition of its merger with Media One, either to spin off its holdings of content provider Liberty Media or its $25 \%$ stake in Time Warner (eventually, AT\&T chose the latter). ${ }^{115}$ In contrast, the AOL-Time Warner combination has stronger incentives-given AOL's dominance as an ISP and the strong content position of Time Warner-not to lease space to rival ISPs than is the case for AT\&T.

Moreover, looking to the future, it bears reemphasizing that no one knows at this point whether any particular broadband technology or company will prove to be dominant. Under these circumstances, "open access" regulation is premature. Regulation is appropriate only if the broadband market (in any relevant geographic region) comes to be dominated by one, or possibly two, competitors.

The regulation of broadband also is not like regulation of other aspects of the Net. Government clearly can be effective in this regard any time it wants, precisely because the providers cannot easily escape jurisdiction. Telephone and cable companies must locate their facilities physically within the United States to provide broadband services. Satellites orbit above the earth, technically outside this country's jurisdiction, but consumers cannot receive the signals without having receivers that are physically located within this country. The wireless providers also cannot provide service in this country without having legal rights to the airspace-or the spectrum, to be precise-to

applicable to AT\&T's ownership of cable systems, because AT\&T's content service pales in numbers compared to the millions of AOL users.

113. FTC Approves AOL/Time Warner Merger with Conditions, at http://www.ftc.gov/opa/ 2000/12/aol.htm (Dec. 14, 2000) (on file with the Duke Law Journal).

114. Seth Schiesel, Dissecting the Deal, N.Y. TimES, Nov. 13, 2000, at C18.

115. Christopher Stern, AT\&T to Spin Off Liberty Media Group, WASH. Post, Nov. 16, 2000, at E1. 
deliver their content. In short, those who provide Internet service can be regulated if the policymakers deem it necessary. It is premature to conclude that this must be the case, however, at least across the board.

Finally, what about the claim by the RBOCs that if broadband cable is not to be subject to open access rules-at least not yet-then they should not be either? Aren't the telephone companies subject to the same disincentives in rolling out DSL that the cable providers purportedly would be if they were subject to open access rules? The short answer seems to be "yes," and thus the most supportable outcome would appear to be to give the RBOCs parity with the cable companies under whatever regime is finally decided. That is, if cable companies are to be subject to open access, then so should the RBOCs (as they are now). If cable broadband providers are not to be subject to open access rules, then neither should the RBOCs-at least, not until it becomes clear that one of the broadband technologies (and thus one of the providers) assumes a dominant position that would require regulation.

\section{WHO REGULATES?}

I shall conclude by providing a few thoughts on one of the most fascinating but challenging aspects of the Internet-namely, who governs the Net-and the policy issues it raises.

Begin with the governance of the Net itself. Somewhat remarkably, there is no governmental entity that sets the rules for communicating on the Internet. Instead, the Net so far has been loosely governed by self-governing bodies that are totally independent of any government.

For example, the languages that enable computers to speak to one another-the so-called "protocols," of which the hypertext transfer protocol (http) and the hypertext markup language (HTML) are the most famous - tend to be developed by individual programmers, or groups of programmers. These languages are then approved by standards bodies, such as the Internet Task Force or the Worldwide Web Consortium. Government-more precisely the U.S. government-was heavily involved for much of the early history of the Internet in establishing and operating the domain name registration system through subcontractors such as the Internet Assigned Num- 
bers Authority (IANA) and Network Solutions, Inc. ${ }^{116}$ This was understandable. The U.S. government, after all, had funded the creation of the Internet.

In 1998, however, the U.S. government heeded calls from both inside and outside this country that the domain name system could not operate indefinitely as a U.S. governmental operation. ${ }^{117}$ Instead, said the argument, the Internet must be devolved to the private sector, ideally in a competitive fashion. Accordingly, in 1998, the Clinton administration called on the private sector to create its own nonprofit organization to manage the domain name and address system. ${ }^{118}$ The result was the formation of the Internet Corporation for Assigned Names and Numbers (ICANN). ICANN has managed a transition from a two-year period when its nineteen directors were appointed to a body whose directors are elected by Internet users. ${ }^{119}$ At this writing, it is in the process of transferring its monopoly over domain name registrations to a competitive environment. ${ }^{120}$

There are many issues that ICANN confronts going forward, even after its selection in November 2000 of seven additional top level domain names (beyond the existing .org, .com, and .edu). ${ }^{121}$ Among the issues facing the organization are the way it manages elections for its directors, and what role, if any, it may or will play in facilitating the resolution of security issues that have arisen on the Net (especially in the wake of various viruses that have, at times, destabilized use of the Net around the world). Space is too short to delve into these subjects here. ${ }^{122}$ I simply note that a body such as ICANN is essentially unprecedented. Historically, governments themselves have created their own multilateral organizations - such as the United Nations, the International Monetary Fund and World Bank, and the

\footnotetext{
116. Developments - The Law of Cyberspace, supra note 1, at 1660-62.

117. Froomkin, supra note 4, at 24; Weinberg, supra note 4, at 204-09.

118. For an excellent discussion of the history, see MANN ET AL., supra note 1, at 158-64.

119. Weinberg, supra note 4, at 225-49.

120. ICANN Announces Selections for New Top-Level Domains, at http://www.icann.org/announcements/icann-pr16nov00.htm (Nov. 16, 2000) (on file with the Duke Law Journal).

121. Ariana Eunjung Cha, Seven New Domain Suffixes Approved, WASH. PosT, Nov. 17, 2000, at E1.

122. For thorough discussions of this topic, see Developments-The Law of Cyberspace, supra note 1, at 1660-80. See generally Froomkin, supra note 4 (discussing the history and development of ICANN and concluding that its future mission should be limited to provide a more decentralized, diverse, and competitive approach to the domain name system); Weinberg, supra note 4 (discussing the legitimacy problem and concluding that ICANN should minimize its policymaking role in order to address concerns related to its exercise of public power).
} 
World Trade Organization-to deal with issues that require some form of multi-national, or extranational, governance. In turn, representatives of the governments that created and still fund these bodies also manage them. Can ICANN, which is no longer supported financially by any government, continue to "govern" cyberspace-to the limited degree that it must-and yet remain independent? Will it be asked to take on issues, such Internet security, which could well lead to some type of multi-government involvement? No one can know the answers for sure, but it is certainly premature to assume that the cyber-libertarian model of the Net-which has envisioned no governmental involvement in governance at all-will continue to be the model for Internet governance in perpetuity.

An equally complex set of issues relates to the questions about jurisdiction on the Internet. Whose law governs taxation, privacy, intellectual property, consumer fraud, and so many other physical world issues that have their counterparts in cyberspace? These questions are difficult enough when applied to transactions and interactions between parties located within one country, such as the United States, but they become even more difficult to answer when the interactions involve parties residing in or organized in different countries.

This subject deserves an article- or book-length treatment that it will not receive here. There is no getting away from the complex choice-of-law questions that inevitably surface on the Internet.

In the long run, however, the appropriate path is clear. Nations should do their best to harmonize their different subject matter laws, or at least enable them to be "interoperable" so that needless conflicts do not arise. ${ }^{123} \mathrm{In}$ fact, there are a number of cross-border initiatives already underway in the areas of commercial law and contracts to develop model laws that would advance this objective. ${ }^{124}$ This is the best that can be hoped for as a united world government is out of the question at any time in the near future.

Meanwhile, in the short run-and perhaps for some significant time for many areas of the law-nations will continue to differ. Whose law will govern in cyberspace? A good first answer is that although the Internet is a new medium of communication, it need notindeed should not-require changing the rules about which law applies to commercial dealings. Typically, that law is governed by the contract dictated by the seller, and it stays that way unless the buyer

123. This is a major theme running through MANN ET AL., supra note 1.

124. Id. at 143-45. 
has significant market power to change the terms. In fact, contracts typically spell out not only the jurisdiction (often the home country where the seller does business or from where it ships its goods) whose law is to apply in the event of a later dispute but also the procedure for resolution, whether it be lodging a complaint in the courts of the seller, or, in some cases, proceeding through binding arbitration or some other form of alternative dispute resolution. This is the way business is conducted now through the mail, by fax, or on the telephone, and the Internet should be no different. Nonetheless, interest in and demand for more efficient means of dispute resolution will grow. Otherwise, there will be a limit to the volume of cross-border transactions conducted through the Internet.

For this reason, there has been some interest in "cyber-tribunals" that would allow parties on both sides of e-transactions to resolve their complaints before specialized arbiters or private judges in cyberspace, without the parties (especially the buyers) having to travel to distant locations and to argue before foreign courts or arbitration panels. ${ }^{125}$ The Federal Trade Commission, which has advocated the creation of these cyber-ADR mechanisms, has also suggested that resolution (and avoidance) of disputes would be easier if governments developed model contracts that consumers and businesses could use in completing Net-based commercial transactions. ${ }^{126}$ Whether these kinds of tribunals or standardized contracts will take off remains to be seen. In the meantime, however, it is "buyer beware" on the Net: buy something in cyberspace and expect your transaction to be covered by the law of the jurisdiction chosen by the seller.

\section{CONCLUSION}

This Essay has touched on some of those challenges and how they might be resolved. I have argued that the solutions are not likely to rest solely with the market or with government, but instead by a

125. The formation of such tribunals is one of the recommendations of a report on jurisdiction in cyberspace issued by the Section of Business Law of the American Bar Association, Achieving Legal and Business Order in Cyberspace: Jurisdictional Issues Created by the Internet (n.d.), http://www.abanet.org/buslaw/cyber/initiatives/jurisdiction.html (on file with the Duke Law Journal).

126. For more details, see Consumer Protection in the Electronic Marketplace: Looking Ahead, at www.ftc.gov/opa/2000/09/globalecommfin.htm (Sept. 6, 2000) (on file with the Duke Law Journal). 
mix of both the market (and technology) and regulation, depending on the particular issue.

This eclectic conclusion almost certainly will not satisfy those in either the libertarian or the regulatory camp. I hope to have shown that there is not much reason to expect that the mix of markets and government that we find in real life will be materially different in cyberspace. To be sure, the nature of the technology should tilt solutions on the Net perhaps more in the direction of market-oriented fixes than in the physical world, but even on the Net, technological solutions are not often present or will not be available for some time. In the interim, government regulation may be called for if users are to trust the Net to do business and engage in other kinds of interaction.

A key challenge for policymakers, when they do act, is to do so in a way that does not frustrate, and ideally that facilitates, the continued search for market-based and and/or technological solutions. Contrary to the view of some libertarians, regulation can be effective for the largest institutions - the "elephants"-that already have major presence on the Internet because of the power of their brand names, and are likely for that reason to maintain or extend that presence in the future.

If evolution of the Internet has proven anything, it is that its twists and turns and the policy issues that it evokes are almost impossible to predict in advance. This requires that policymakers not act prematurely. When they do act, though, they must do so pragmatically and with a humility that allows for constant mid-course corrections. 